\title{
PENGARUH METODE PEMBELAJARAN RECIPROCAL BERBANTUAN FEEDBACK VISUAL TERHADAP HASIL BELAJAR LOMPAT JAUH PADA PESERTA DIDIK KELAS VIII SMP NEGERI 1 MENGWI TAHUN PELAJARAN 2018/2019
}

\author{
I Putu Adi Eka Prabawa1', I Nyoman Kanca², Made Agus Wijaya ${ }^{3}$ \\ Fakultas Olahraga dan Kesehatan \\ Undiksha \\ e-mail:prabawa55@gmail.com,kanca.nyoman@yahoo.co.id, \\ wijaya.madeagus@undiksha.ac.id
}

\begin{abstract}
Abstrak
Penelitian ini bertujuan untuk mengetahui pengaruh metode pembelajaaran reciprocal berbantuan feedback visual terhadap hasil belajar lompat jauh. Jenis penelitian adalah eksperimen sungguhan (true experimental) dengan rancangan the randomized pretest-posttest control group the same subjec design. Populasi penelitian adalah seluruh peserta didik kelas VIII SMP Negeri 1 Mengwi tahun pelajaran 2018/2019, berjumlah 11 kelas dengan populasi 386 orang. Pengambilan sampel menggunakan simple random sampling berdasarkan kelas. Kelas yang menjadi sampel penelitian adalah kelas VIII G sebanyak 34 orang sebagai kelompok eksperimen dan VIII H sebanyak 36 orang sebagai kelompok kontrol. Eksperimen dilakukan sebanyak 2 kali perlakuan di luar pretes-posttest. Data hasil belajar dikumpulkan melalui tes esay, observasi dan unjuk kerja. Analisis data menggunakan uji-t dengan bantuan SPSS 16.0 for Windows. Signifikansi pada uji hipotesis diperoleh melalui uji parametrik (uji Independent Samples Test) adalah 0.02 yaitu $\mathrm{p}<0,05$. Disimpulkan bahwa metode pembelajaaran reciprocal berbantuan feedback visual berpengaruh signifikan terhadap peningkatan hasil belajar lompat jauh gaya jongkok dan gaya menggantung di udara. Disarankan kepada guru Pendidikan Jasmani Olahraga Kesehatan dapat menerapkan metode pembelajaaran reciprocal berbantuan feedback visual karena terbukti berpengaruh signifikan terhadap hasil belajar lompat jauh peserta didik.
\end{abstract}

Kata-kata kunci: metode pembelajaran reciprocal, feedback visual, hasil belajar, lompat jauh.

\begin{abstract}
This reseach aims to determine the effect of visual feedback assisted reciprocal learning methods on learning outcomes of long jump. This research was a true experiment (true experimental) with the randomized pretest-posttest control group design the same subject design. The research population was all students of class VIII SMP Negeri 1 Mengwi in the 2018/2019 school year, with a total of 11 classes with a population of 386 people. Sampling used simple random sampling based on class. The class into the sample was class VIII G as the experimental group and VIII $\mathrm{H}$ as the control group. Experiments carried out 2 times the treatment outside the pretest-posttest. Data were collected through essay tests, observations and performance. Data analysis using t-test with SPSS 16.0 for Windows. The significance of the hypothesis test obtained through the parametric test (Independent Samples Test) is 0.02 , which is $p<0.05$. It was concluded that the reciprocal learning method assisted by visual feedback significantly influenced the long jump learning result. It is recommended to Physical Education teachers be able to apply reciprocal learning methods assisted with visual feedback because it is proven to have a significant effect on student learning outcomes.
\end{abstract}

Key words: reciprocal learning methods, feedback visual, learning outcome, techniques long jump.

\section{PENDAHULUAN}

Proses pembelajaran merupakan inti dari kegiatan pendidikan di sekolah khususnya dalam pembelajaran Pendidikan Jasmani Olahraga dan
Kesehatan (PJOK). Pembelajaran PJOK bertujuan untuk membantu peserta didik dalam usaha meningkatkan derajat kesehatan dan kebugaran jasmani melalui keterampilan gerak dasar dalam berbagai 
aktivitas jasmani. Dengan demikian dalam kegiatan pembelajaran PJOK selalu bersentuhan dengan aktivitas gerak fisik. Aktivitas gerak fisik tersebut akan tampak dalam aktivitas gerak peserta didik saat melakukan tugas-tugas gerak dalam proses pembelajaran.

PJOK merupakan pendidikan melalui aktivitas jasmani yang dijadikan sebagai media untuk mencapai suatu perkembangan individu secara menyeluruh. PJOK tidak hanya sekedar melibatkan fisik semata, tetapi juga harus memberi dampak terhadap perkembangan intelektual peserta didik dan harus membantu peserta didik terampil berpikir dan dapat mengembangkan sikap, karakter dan kepribadian.

Setiap individu memiliki kebutuhan yang berbeda-beda, pembelajaran secara individu pada dasarnya merupakan pembelajaran untuk semua peserta didik, termasuk program untuk peserta didik yang mempunyai kelambatan dalam perkembangannya, gangguan emosional, dan memiliki cacat fisik atau mental. Pada dasarnya pembelajaran tidak hanya memperhatikan perolehan akademisnya akan tetapi juga kemampuan bicara, koordinasi, dan keterampilan sosialnya. Salah satu cara agar dapat menciptakan manusia yang cerdas adalah melalui peningkatan hasil belajar. Untuk dapat meningkatkan hasil belajar dengan baik, perlu memperhatikan faktor-faktor yang mempengaruhi hasil belajar. Adapun yang mempengaruhi hasil belajar adalah faktor internal dan eksternal. Faktor internal yaitu faktor yang ada dalam diri peserta didik, dan faktor eksternal yaitu faktor yang ada di luar diri peserta didik. Salah satunya adalah sekolah, di dalam proses pembelajaran di sekolah sangat erat kaitanya dengan metode pembelajaran yang digunakan. Metode yang baik memberikan dampak positif pada kegiatan pembelajaran, sehingga pembelajaran menjadi kondusif, menyenangkan dan menarik. Hal tersebut dikarenakan semakin baik guru menerapkan metode pembelajaran semakin baik pula peserta didik memahami materi pembelajaran, sebaliknya guru yang kurang menguasai metode dalam proses pembelajaran, kurangnya persiapan dalam pembelajaran dan penyajiannya kurang jelas menyebabkan peserta didik kurang memahami pembelajaran dan akan berdampak pada hasil belajar yang diperoleh peserta didik.

Melihat kenyataan sekarang ini kebanyakan guru PJOK memberikan materi pembelajaran kepada peserta didik hanya sebatas peragaan, contoh gerakan kemudian akan dilakukan evaluasi setelah proses pembelajaran selesai, disini peserta didik tidak akan mudah untuk memahami dimana letak kesalahan dan kekurangan mereka dalam mengikuti proses pembelajaran.

Berdasarkan informasi dan data yang diperoleh dari guru PJOK kelas VIII SMP Negeri 1 Mengwi, hasil belajar PJOK peserta didik di kelas VIII dapat dikatakan kurang, nilai yang diambil sebagai sampel adalah dari kelas G dan H SMP Negeri 1 Mengwi. Pada hasil belajar lompat Jauh, masih banyak peserta didik yang nilainya di bawah kreteria ketuntasan minimal (KKM) 70 dalam pembelajaran PJOK. Hasil belajar peserta didik kelas $G$ yang berjumlah 34 orang, peserta didik yang nilainya tuntas 12 orang (35\%) dan yang tidak tuntas 22 orang (65\%). Sedangkan dikelas $\mathrm{H}$ yang berjumlah 36 orang. Peserta didik yang nilainya tuntas 16 orang $(44 \%)$ dan yang tidak tuntas 20 orang $(66 \%)$ Sehingga dapat disimpulkan bahwa hasil belajar lompat jauh kelas VIII SMP Negeri 1 Mengwi dikatakan belum sepenuhnya mencapai ketuntasan secara maksimal.

Hasil belajar peserta didik yang tidak tuntas tersebut dikarenakan adanya masalah-masalah yang menjadi kendala saat pembelajaran berlangsung. Kurangnya inovasi dalam proses pembelajaran membuat peserta didik merasa bosan, gaya guru mengajar yang kurang memperhatikan peserta didik, situasi saat mengajar yang kurang baik dan memadai adalah suatu penyebab dari hasil belajar peserta didik yang cenderung rendah dan dinyatakan tidak tuntas. Dengan demikian diperlukan adanya inovasi dalam hal pengelolaan kelas baik dalam penggunaan metode pembelajaran dan variasi guru dalam penyampaian 
materi sehingga dapat memperbaiki hasil belajar peserta didik. Metode pembelajaran yang tepat diyakini dapat memperbaiki hasil belajar peserta didik. Salah satunya adalah metode pembelajaran reciprocal berbantuan feedback visual yang berguna untuk membantu peserta didikdalam peningkatan hasil belajar sehingga hasil belajarpeserta didik dapat mencapai KKM.

Metode pembelajaran reciprocal berbantuan feedback visual merupakan konsep baru dalam pembelajaran yang dapat merangsang peserta didik untuk belajar mandiri, kreatif, dan lebih aktif dalam mengikuti kegiatan pembelajaran, juga dapat membantu memecahkan permasalahan yang sering dihadapi dalam penggunaan metode pembelajaran yang lain, membantu peserta didik untuk mengembangkan pengertian atau pemahaman konsep secara lengkap serta dapat membantu peserta didik mengembangkan kemampuan untuk menjadi pemikir yang mandiri.

Seorang guru sangatlah penting didalam menerapkan metode pembelajaran, disamping itu juga harus disesuaikan dengan kebutuhan dan kondisi peserta didik, sehingga dapat memacu peserta didik untuk ikut berperan aktif terhadap materi pembelajaran yang diberikan. Oleh karena itu peneliti mencoba memberikan salah satu alternatif pemecahan masalah yaitu dengan menerapkan metode pembelajaran reciprocal berbantuan feedback visual.

Penelitian tentang hasil belajar dengan menggunakan metode reciprocal dikuatkan oleh penelitian terdahulu diantaranya, (1) । Gede Ariyasa dkk (2014), dengan judul pengaruh model pembelajaran reciprocal teaching terhadap hasil belajar IPA Peserta didik kelas $V$ SD Negeri 1 Tulamben, menemukan bahwa terdapat perbedaan yang signifikan terhadap hasil belajar IPA antara kelompok Peserta didik yang dibelajarkan dengan model pembelajaran reciprocal teaching dan Peserta didik yang dibelajarkan dengan model pembelajaran konvensional. (2) Dwi Rachmayani(2014), dengan judul penerapan pembelajaran reciprocal teaching untuk meningkatkan kemampuan komunikasi matematis dan kemandirian belajar matematika Peserta didik, menemukan bahwa kemampuan komunikasi matematis Peserta didik yang mempergunakan pembelajaran reciprocal teaching lebih baik dari pada Peserta didik yang menggunakan pembelajaran langsung. (3) I Gede Ariyasa dkk (2014), dengan judul pengaruh model pembelajaran reciprocal teaching terhadap hasil belajar IPA Peserta didik kelas $V$ SD Negeri 1 Tulamben, menemukan bahwa terdapat perbedaan yang signifikan terhadap hasil belajar IPA antara kelompok Peserta didik yang dibelajarkan dengan model pembelajaran reciprocal teaching dan Peserta didik yang dibelajarkan dengan model pembelajaran konvensional. (4) Ayana A Panjaitan (2015), menyatakan bahwa ada pengaruh yang positif dan signifikan model pembelajaran Reciprocal Teaching terhadap hasil belajar ekonomi peserta didik Kelas IX IPS SMA Negeri 1 Lumban Julu tahun pembelajaran 2014/2015.

Berdasarkan permasalahan di atas, maka peneliti melakukan penelitian dengan judul "Pengaruh Metode Pembelajaran Reciprocal Berbantuan Feedback Visual Terhadap Hasil Belajar Lompat Jauh Peserta didik Kelas VIII SMP Negeri 1 Mengwi Tahun Pelajaran 2018/2019".

\section{KAJIAN TEORI}

Aktivitas kehidupan manusia sehari-hari hampir tidak pernah dapat terlepas dari kegiatan belajar. Menurut Burton (dalam Aunurrahman, 2009: 35) belajar sebagai perubahan tingkah laku pada diri individu berkat adanya interaksi antar individu dan individu dengan lingkungannya sehingga mereka mampu berinteraksi dengan lingkungannya. Belajar adalah proses dimana tingkah laku ditimbulkan atau diubah melalui latihan dan pengalaman, James $O$. Whittaker (dalam Aunurrahman, 2009: 35). Dari pendapat di atas, belajar dapat diartikan sebagai perubahan tingkah laku yang terjadi karena adanya interaksi individu dengan individu maupun lingkungan yang 
terjadi melalui proses latihan dan pengalaman.

Teori-teori yang berkaitan dengan proses belajar juga dikemukakan oleh para ahli diantaranya: (1) Teori belajar Thorndike, (2) Teori belajar Skinner, (3) Teori belajar Bandura.

(1)Teori belajar Thorndike, menyimpulkan bahwa belajar bersifat bertahap, bukan langsung ke pengertian. (2) menurut Skinner, belajar akan berlangsung sangat efektif apabila informasi yang dipelajari disajikan secara bertahap, dan pembelajaran segera diberi umpan balik (feedback) mengenai akurasi pembelajaran mereka (yakni, setelah belajar mereka segera diberi tahu apakah mereka sudah memahami informasi dengan benar atau tidak) dan pembelajar mampu belajar dengan caranya sendiri. (3) Teori belajar Bandura, yang menyebutkan bahwa kita belajar dengan mengamati orang lain dan bahwa belajar ini terjadi dengan atau tanpa imitasi dan tanpa penguatan.

Penelitian dengan menggunakan metode reciprocal berbantuan feedback visual dikuatkan dengan dikemukakannya teori belajar Skinner yang menyebutkan bahwa, belajar akan berlangsung sangat efektif apabila informasi yang dipelajari disajikan secara bertahap, dan pembelajaran segera diberi umpan balik (feedback) mengenai akurasi pembelajaran mereka (yakni, setelah belajar mereka segera diberi tahu apakah mereka sudah memahami informasi dengan benar atau tidak) dan pembelajar mampu belajar dengan caranya sendiri.

Metode pengajaran terbalik (reciprocal) adalah metode belajar melauai kegiatan mengajarkan teman, metode ini Peserta didik berperan sebagai guru menggantikan guru untuk mengajarkan teman temannya. Dengan pengajaran terbalik guru mengajarkan peserta didik keterampilan-keterampilan pengetahuan penting dengan menciptakan pengalaman belajar, kemudian membantu peserta didik mengembangkan keterampilan tersebut atas usaha mereka sendiri dengan pemberian semangat dan dukungan.

Metode pembelajaran reciprocal merupakan konsep baru dalam pembelajaran yang dapat merangsang peserta didik untuk belajar mandiri, kreatif, dan lebih aktif dalam mengikuti kegiatan pembelajaran. Dimana peserta didik diberi kesempatan untuk mempelajari materi terlebih dahulu, kemudian peserta didik menjelaskan kembali materi yang dipelajari kepada pasanganya. Guru hanya bertugas sebagai fasilitator dan pembimbing dalam pembelajaran, yaitu meluruskan atau memberi penjelasan mengenai materi yang tidak dapat dipecahkan secara mandiri oleh peserta didik. Ciri dari metode pembelajaran ini adalah kelas diorganisasi/dibuat formasi dalam bentuk pasangan-pasangan. Setiap anggota dalam pasangan memiliki peran khusus dan adanya proses umpan balik. Dalam pasangan satu orang dirancang sebagai pelaku, yang lain sebagai pengamat. Pelaku menampilkan tugas gerak dan pengamat memberi umpan balik kepada pelaku berdasarkan kriteria yang disiapkan oleh guru. Umpan balik ini terjadi selama pelaku melakukan unjuk kerja atau selesai penampilan keseluruhan tugas yang ada, bila sudah selesai berganti peran.

Keunggulan
pembelajaran reciprocal, selain dapat
meciptakan pemahaman baru yang menuntut aktivitas kreatif, produktif dalam konteks nyata yang mendorong peserta didik untuk berpikir ulang lalu mendemontrasikan, metode ini juga dapat memotivasi peserta didik bahwa belajar adalah tanggung jawab peserta didik itu sendiri, peserta didik belajar dengan pemahaman sehingga tidak mudah lupa dan belajar bisa lebih bermakna, dapat mengembangkan kemampuan peserta didik untuk mengajukan pertanyaan dan mencari jawabannya sendiri. Dapat membantu peserta didik untuk mengembangkan pengertian atau pemahaman konsep secara lengkap. Dan dapat membantu peserta didik mengembangkan kemampuan untuk menjadi pemikir yang mandiri.

$$
\text { Langkah-langkah Metode }
$$

Pembelajaran Reciprocal Menurut Aris Shoimin (2014:153) Metode pembelajaran reciprocalmerupakan sebuah metode pembelajaran berupa kegiatan 
mengajarkan materi kepada teman, dalam metode pembelajaran ini Peserta didik berperan sebagai guru untuk menyampaikan materi kepada temannya, sementara itu guru lebih berperan sebagai model yang menjadi fasilitator dan pembimbing.

\section{METODE PENELITIAN}

Jenis penelitian adalah eksperimen sungguhan (true experimental). Kanca, (2010: 86) menyatakan, Tujuan dari penelitian eksperimen sungguhan adalah untuk menyelidiki kemungkinan saling hubungan sebab-akibat dengan cara mengenakan kepada satu atau lebih kelompok eksperimental satu atau lebih kondisi perlakuan dan memperbandingkan hasilnya dengan satu atau lebih kelompok kontrol yang tidak dikenai kondisi perlakuan.

Rancangan penelitian adalah
"rencana tantang bagaimana cara
mengumpulkan, menyajikan, dan menganalisa data untuk memberi arti terhadap data tersebut secara efektif dan efesien" (Kanca, 2010: 55). Menggunakan Rancangan the randomized pretestpostest control group the same subject design.

Penelitian ini bertujuan untuk mengetahui pengaruh metode reciprocal berbantuan feedback visual terhadap hasil belajar lompat jauh pada peserta didik kelompok eksperimen, sedangkan kelompok kontrol diberikan pembelajaran dengan metode konvensional (Ceramah).

Populasi pada penelitian ini adalah seluruh pesrta didik kelas VIII SMP Negeri 1 Mengwi, sebanyak 386 orang peserta didik dibagi kedalam 11 kelas. Pengambilan sampel dalam penelitian dilakukan dengan cara merandom seluruh kelas yang terdapat di kelas VIII SMP Negeri 1 Mengwi. Dengan ketentuan kelas yang pertama keluar setelah diundi adalah sebagai kelas perlakuan (eksperimen) dan yang keluar kedua sebagai kelas kontrol.

Analisis data menggunakan Uji-t dengan berbantuan SPSS 16.00 for windows. Sebelum diuji-t data terlebih dahulu diuji normalitas dan homogenitas.

\section{HASIL DAN PEMBAHASAN}

Dalam penelitian ini kelompok eksperimen yaitu kelas $G$ diberikan perlakuan berupa metode reciprocal berbantuan feedback visual dan pada kelompok kontrol yaitu kelas $\mathrm{H}$ diberikan perlakuan dengan menggunakan metode konvensional (ceramah).

Penelitian dilaksanakan di lapangan Mengwi, Badung. Data berupa nilai yang diperoleh dari pretest dan posttest. Kemuadian nilai tersebut dianalisis menggunakan gain skor ke dalam SPSS 16.00 for Windows.

Tabel 01. Uji Normalitas

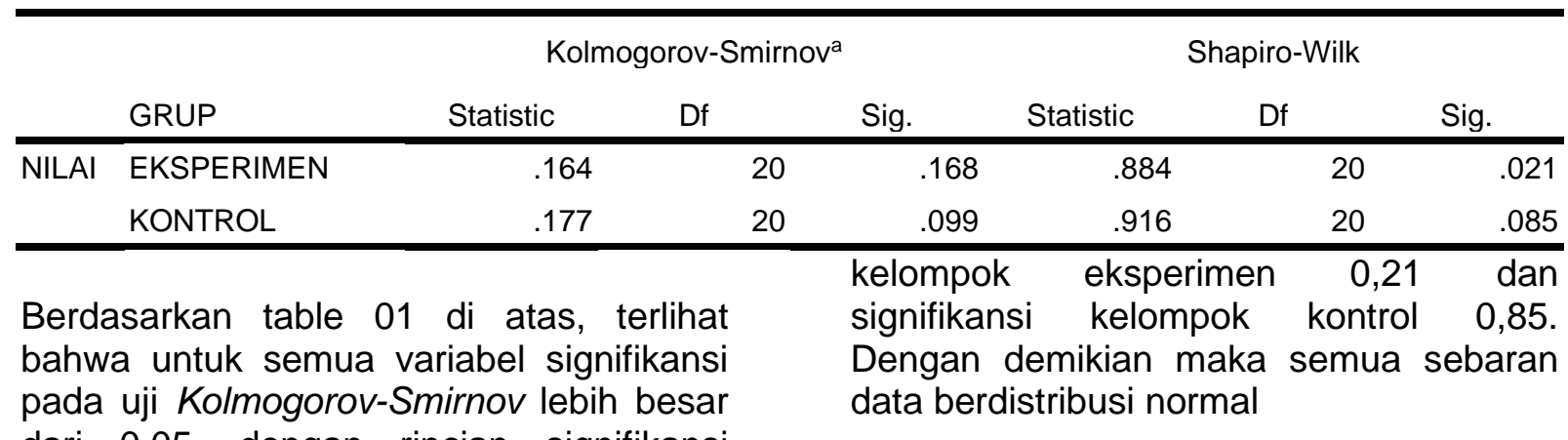


Tabel 02. Uji Homogenitas

\begin{tabular}{|c|c|c|c|c|}
\hline Levene Statistic & df1 & df2 & & Sig. \\
\hline .201 & 1 & & 38 & .657 \\
\hline
\end{tabular}

Berdasarkan tabel 02 . hasil uji Levene's menunjukkan bahwa untuk hasil belajar lompat jauh dengan taraf signifikansi 0,657 lebih besar dari 0,05. sehingga dapat disimpulkan bahwa variansi pada setiap kelompok adalah sama homogeny.

Tabel 03. Uji-t

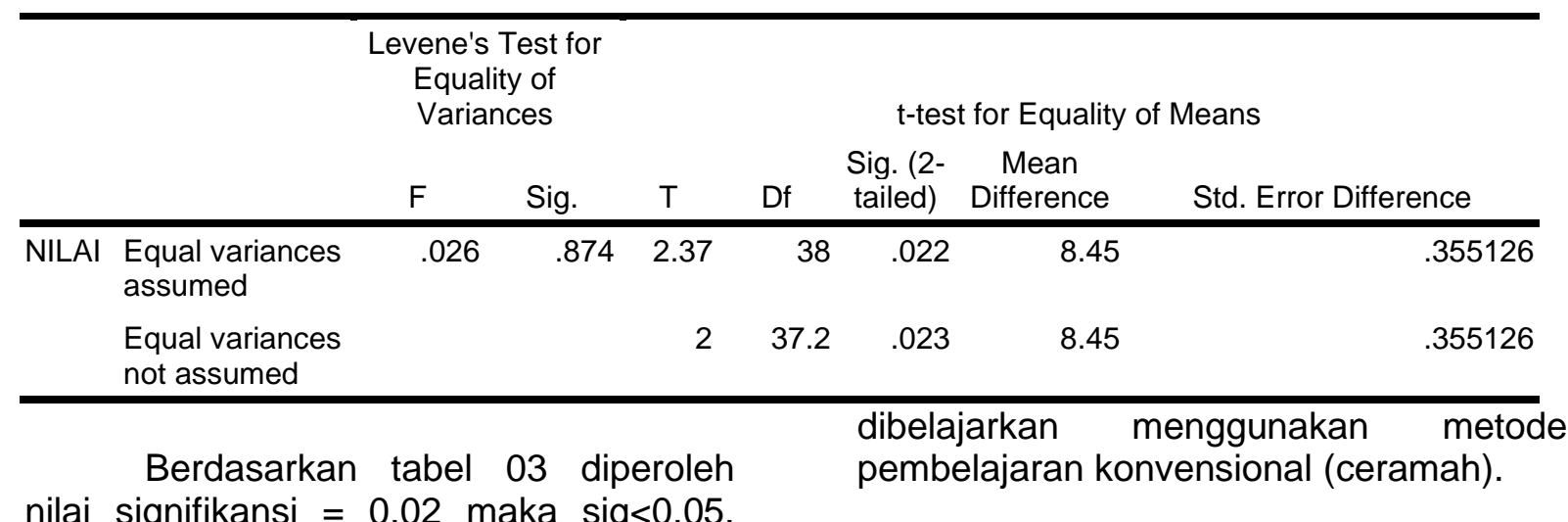

nilai signifikansi $=0,02$ maka sig<0,05. Hasil ini dijadikan dasar dalam mengambil keputusan. Adapun keputusan yang diambil adalah tolak Ho dan terima $\mathrm{Ha}$. Hasil ini menyatakan bahwa terdapat perbedaan hasil belajar lompat jauh antara peserta didik yang dibelajarkan menggunakan metode reciprocal berbantuan feedback visual dengan peserta didik yang dibelajarkan menggunakan metode pembelajaran konvensional (ceramah).

Berdasarkan angka rata-rata terlihat bahwa rata-rata peningkatan hasil belajar pada kelompok eksperimen lebih besar daripada kelompok kontrol. Dapat disimpulkan bahwa hasil belajar pada siswa yang dibelajarkan menggunakan metode reciprocal berbantuan feedback visual lebih tinggi daripada siswa yang

\section{PEMBAHASAN}

Keberhasilan proses pembelajaran tidak terlepas dari kemampuan guru mengembangkan metode yang digunakan dalam proses pembelajaran yang berorientasi pada peningkatan keterlibatan peserta didik secara aktif dalam proses pembelajaran. Penggunaan metode pembelajaran yang tepat pada dasarnya bertujuan untuk menciptakan kondisi pembelajaran yang memungkinkan peserta didik dapat belajar secara aktif dan menyenangkan.

Metode pembelajaran reciprocal berbantuan feedback visual, merupakan metode pembelajaran yang dapat merangsang peserta didik untuk belajar mandiri, kreatif, dan lebih aktif dalam mengikuti kegiatan pembelajaran, dengan ciri kelas diorganisasi/dibuat formasi dalam bentuk pasangan. Setiap anggota dalam pasangan memiliki peran khusus 
dan terdapat proses pemberian umpan balik. Dalam pasangan satu orang dirancang sebagai pelaku, yang lain sebagai pengamat. Pelaku menampilkan tugas gerak dan pengamat merekam gerakan yang dilakukan pelaku serta membandingkan gerakan dengan kriteria yang diberikan oleh guru, dan sesegera mungkin memberi umpan balik kepada pelaku berdasarkan kriteria dan hasil rekaman gerakan pelaku sendiri, umpan balik ini terjadi selama pelaku melakukan unjuk kerja atau selesai penampilan keseluruhan tugas yang ada, bila sudah selesai mereka berganti peran. Dengan menggunakan metode ini kondisi kelas menjadi kondusif, pembelajaran menyenangkan, dan peserta didik turut aktif dalam proses pembelajaran, sehingga hasil belajar peserta didik bisa lebih meningkat.

Keunggulan metode pembelajaran reciprocal, selain dapat meciptakan pemahaman baru yang menuntut aktivitas kreatif, produktif dalam konteks nyata yang mendorong peserta didik untuk berpikir ulang lalu mendemontrasikan, metode ini juga dapat memotivasi peserta didik bahwa belajar adalah tanggung jawab peserta didik itu sendiri, peserta didik belajar dengan pemahaman sehingga tidak mudah lupa dan belajar bisa lebih bermakna, dapat mengembangkan kemampuan peserta didik untuk mengajukan pertanyaan dan mencari jawabannya sendiri. Dapat membantu peserta didik untuk mengembangkan pengertian atau pemahaman konsep secara lengkap. Dan dapat membantu peserta didik mengembangkan kemampuan untuk menjadi pemikir yang mandiri.

Berdasarkan hasil analisis data diperoleh bahwa terdapat perbedaan hasil belajar Lompat Jauh dalam metode pembelajaran reciprocal berbantuan feedback visual dengan metode pembelajaran konvensional, ini berarti metode pembelajaran reciprocal berbantuan feedback visual berpengaruh signifikan terhadap hasil belajar Lompat jauh.

Hal ini sejalan dengan penelitian yang dilakukan oleh Ami Ariasti kadek
(2018) menemukan bahwa metode pembelajaran reciprocal berbantuan feedback visual berpengaruh signifikan terhadap peningkatan hasil belajar PJOK pada peserta didik kelas $X$ di SMA Negeri 1 Sukasada. Dwi Rachmayani (2014), menemukan bahwa kemampuan komunikasi matematis Peserta didik yang mempergunakan pembelajaran reciprocal teaching lebih baik dari pada Peserta didik yang menggunakan pembelajaran langsung. I Gede Ariyasa dkk (2014), dengan judul pengaruh model pembelajaran reciprocal teaching terhadap hasil belajar IPA Peserta didik kelas $V$ SD Negeri 1 Tulamben, menemukan bahwa terdapat perbedaan yang signifikan terhadap hasil belajar IPA antara kelompok Peserta didik yang dibelajarkan dengan model pembelajaran reciprocal teaching dan Peserta didik yang dibelajarkan dengan model pembelajaran konvensional. Ayana A Panjaitan (2015), menyatakan bahwa ada pengaruh yang positif dan signifikan model pembelajaran Reciprocal Teaching terhadap hasil belajar ekonomi peserta didik Kelas IX IPS SMA Negeri 1 Lumban Julu tahun pembelajaran 2014/2015.

Dari uraian di atas memberikan gambaran bahwa metode reciprocal berbantuan feedback visual berpengaruh signifikan terhadap hasil belajar lompat juah. Hasil penelitian ini memberikan implikasi bahwa terdapat perbedaan hasil belajar pada materi lompat jauh antara Peserta didik yang dibelajarkan menggunakan metode pemblajaran reiciprocal berbantuan feedback visual dengan peserta didik yang dibelajarkan dengan menggunakan metode pembelajaran konvensional (ceramah).

\section{DAFTAR PUSTAKA}

Undiksha. 2016. Pedoman Penulisan Karya Ilmiah Tugas Akhir, Skripsi, Tesis, dan Disertasi. Singaraja: Undiksha.

Ariyasa, Gede. 2014. "PengaruhModel Pembelajaran Reciprocal Teaching Terhadap Hasil belajar Ipa Peserta 
didik Kelas V Sd Negeri 1Tulamben" Tersedia pada:http://download.portalgaruda. org/article. (Diakses pada 28 September 2017).

Aunurrahman. 2009. Belajar dan Pembelajaran. Bandung: Alfabeta CV.

Chandra Asri. 2016. "Aplikasi Teori Umpan Balik (Feedback) Dalam Pembelajaran Motorik Pada Anak Usia Dini" Tersedia pada: https://www.google.com/search?cli ent=firefoxbab\&q=jurnal+eksperim en+chandra+asri+aplikasi+teori+u mpan+balik(feedback)+dalam+pem belajaran+motorik+pada+anak+usi a+dini.(Diakses pada 28 September 2017).

Dimyati dan Mudjiono. 2006. Belajar dan Pembelajaran. Jakarta: Rineka Cipta.

Djmarah, Syaiful Bahri dan Aswan Zain. 2006. Strategi Belajar Mengajar. Jakarta: PT Asdi Mahasatya.

Huda, Miftahul. 2013. Model-model pengajaran dan pembelajaran. Yogyakarta: pustaka Pelajar.

Kanca, I Nyoman. 2010. Metode Penelitian Pengajaran Pendidikan Jasmani dan Olahraga. Singaraja: Universitas Pendidikan Ganesha.

Parwata, Lanang Agung\& Dkk. 2010. Buku Ajar Aktivitas Atletik. Singaraja: Universitas Pendidikan Ganesha.

Rachmayani, Dwi. 2014. "Penerapan PembelajaranReciprocal Teaching Untuk Meningkatkan Kemampuan Komunikasi Matematis Dan Kemandirian Belajar Matematika Peserta didik". Tersedia pada: https://journal.unsika.ac.id/index.ph p/judika/article/view/118/122.(Diaks es pada 28 September 2017).
Shoimin, Aris.2014. 68 Model Pembelajaran Inovatif dalam Kurikulum 2013. Yogyakarta: ARRUZZ MEDIA.

Sudjana, Nana. 2004. Penilaian Hasil Proses Belajar Mengajar. Bandung: Pt. Remaja Rosdakarya.

Sudrajat dan Syarifudin. 2014. Pendidikan Jasmani Olahraga, dan Kesehatan. Jakarta: Pusat Kurikulum dan Perbukuan, Balitbang, Kemdikbud.

Suryosubroto, B. 2002. Proses Belajar Mengajar di Sekolah. Jakarta: PT Rineka Cipta.

Wati, Ega Rima. 2016. Ragam Media Pembelajaran. Jakarta: Kata Pena.

Ariasti, Kadek Ami. 2018. Pengaruh Metode Pembelajaran Reciprocal Berbantuan Feedback Visual Terhadap Hasil Belajar PJOK Siswa Kelas X Sma Negeri 1 Sukasada Tahun Pelajaran 2018/2019. Singaraja: Undiksha 